Sains Malaysiana 49(5)(2020): 1145-1152

http://dx.doi.org/10.17576/jsm-2020-4905-20

\title{
The Application of Lognormal Distribution on the New Two-Sided Group Chain Sampling Plan
}

(Pengaplikasian Taburan Lognormal ke atas Plan Persampelan Berangkai Dua Sisi secara Kumpulan yang Baharu)

\author{
MUHAMMAD FAROUK*, NAZRINA AZIZ \& ZAKIYAH ZAIN
}

\begin{abstract}
This paper gives emphasis on the technical aspect of acceptance criteria in acceptance sampling plans, more specifically the family of two-sided group chain sampling plans. The new two-sided complete group chain sampling plan (NTSCoGCh) operates with five acceptance criteria, while the two-sided group chain sampling plan (TS-GCh) operates with three acceptance criteria. Generally, the number of acceptance criteria has a direct influence on the probability of lot acceptance; the more criteria being accepted leads to higher probability of lot acceptance. This paper suggests a new, balanced plan for the family of two-sided group chain sampling plans. The plan, named the new two-sided group chain sampling plan (NTSGCh), operates with four acceptance criteria. The Lognormal distribution is used to represent the production sequence of manufactured products in this study. A time truncated life test simulation is carried out to obtain the minimum number of groups required and the probability of lot acceptance. The findings show that the NTSGCh outperformed its predecessors. In conclusion, the NTSGCh is a viable alternative for implementation in the industry.
\end{abstract}

Keywords: Acceptance sampling; lognormal distribution; truncated life test

ABSTRAK

Makalah ini memberi penekanan kepada aspek teknikal iaitu kriteria penerimaan di dalam persampelan penerimaan, terutamanya kepada gugusan pelan persampelan berangkai dua sisi secara berkumpulan. Pelan persampelan lengkap berangkai dua sisi secara berkumpulan yang baru (NTSCoGCh) beroperasi dengan menggunakan lima kriteria penerimaan, manakala pelan persampelan berangkai dua sisi secara berkumpulan (TS-GCh) beroperasi dengan menggunakan tiga kriteria penerimaan. Umumnya, bilangan kriteria penerimaan mempunyai pengaruh langsung pada kebarangkalian penerimaan lot; lebih tinggi bilangan kriteria penerimaan, maka kebarangkalian penerimaan lot juga meningkat. Makalah ini mencadangkan pendekatan baru dan lebih seimbang dalam persampelan penerimaan yang dinamakan pelan persampelan berangkai dua sisi secara berkumpulan yang baru (NTSGCh). Pelan ini beroperasi menggunakan empat kriteria penerimaan. Serakan Lognormal telah digunakan di dalam kajian ini. Simulasi ujian hayat terpenggal telah dijalankan untuk mendapatkan jumlah minima kumpulan dan juga kebarangkalian penerimaan lot. Keputusan kajian menunjukkan bahawa NTSGCh memberikan keputusan yang lebih baik berbanding kedua-dua pelan persampelan terdahulu. Kesimpulannya, NTSGCh merupakan satu alternatif yang baik untuk digunakan dalam proses pemeriksaan lot di industri.

Kata kunci: Persampelan penerimaan; taburan Lognormal; ujian hayat terpenggal

\section{INTRODUCTION}

Acceptance sampling plays an important role in the quality control process in the manufacturing industry. It helps manufacturers save time and costs during inspection while still remaining confident that most of the manufactured products adhere to the quality level that is needed. The concept of total inspection is the best way to ensure that every product conforms to the level of quality specified. Total inspection, otherwise known as $100 \%$ inspection, involves inspecting each product for non-conformities. Conforming products are accepted for the next process while non-conforming products are acted upon, such as being reworked or scrapped. As good as it sounds, however, total inspection is not practical for modern day, big scale manufacturing for a few obvious reasons.

Firstly, total inspection requires lots of manpower and time for the inspection process. A manufacturing company would need to hire plenty of product inspectors to conduct the inspection, and with the product volume are in the tens of thousands, inspecting each and every product will take a long time to complete. Hence, it can be said that total inspection is both time and resource consuming. Secondly, total inspection is also irrelevant when it comes to manufacturing products that are perishable in nature. A good example of such product 
is food product. For instance, consider the production of instant noodles. The inspection of instant noodles production would require the inspectors to cook the instant noodles in order to ascertain that it can be cooked in the suitable time, while maintaining the specified quality level of texture and taste. If total inspection is to be conducted, then each of the instant noodles will perish and no longer be sellable. Hence, in such cases, total inspection is not an option.

Acceptance sampling involves taking a sample of products from a production lot for inspection. If the result of inspection conforms to the specified acceptance criteria, then the whole production lot is accepted for further processing. Thus, acceptance sampling provides the manufacturers an alternative in the decision-making process of lot sentencing. However, acceptance sampling also has its own drawbacks, namely the errors that may happen during inspection. Type-I error, or also known as producer's risk or -risk, refers to the probability of rejecting a good lot (Montgomery 2009). For example, a company is only willing to have a $10 \%$ defective rate in its production. A sample of 10 products are drawn from a production lot of 100 products for inspection. It is found that out of the 10 inspected products, 3 are found to be defective, which is more than the pre-specified acceptance number of 1 . Hence, the production lot is rejected. However, in the remaining 90 products that were not sampled, there are no defectives present. Thus, in actual, the production lot has less than $10 \%$ defective rate and should have been accepted. Such errors made during inspection are a risk to the producers, hence named the producer's risk.

Type-II error, which is also known as consumer's risk or $\beta$-risk, refers to the probability of accepting a bad lot (Montgomery 2009). It is the direct opposite of type-I error. Type-II error happens during sampling of products for inspection, where the sample consists of conforming products, but the unsampled products consists of a number of non-conforming products. Thus, it poses a potential risk to the consumers who might be receiving defective products at their end. Hence, it is named as the consumer's risk.

Over the years since its inception, acceptance sampling techniques have gone through many stages of development. The first technique that was introduced is the single sampling plan (SSP), in the year of 1954 . The SSP has been worked on a number of distributions, such as the Weibull distribution (Goode \& Kao 1961), the Inverse Rayleigh distribution (Rosaiah \& Kantam 2005) and the Log-logistic distribution (Kantam et al. 2001). It involves only taking one sample from the production lot for inspection. An extension to the SSP is the double sampling plan (DSP), where two samples are taken from the production lot for inspection. Like the SSP, the DSP also has been tested with various distributions, such as the Weibull distribution (Aslam et al. 2009), the Rayleigh distribution (Aslam 2007), and the Generalized Log-logistic distribution (Aslam \& Jun 2010).

Dodge (1955) proposed a plan called the chain sampling plan (ChSP-1). This plan not only requires inspection on a sample of products from the current production lot but it also considers the result from the previous production lot. The production lot can only be accepted if cumulatively, both the previous and current production lot has at most 1 defective product. The ChSP1 has also been tested using the Weibull distribution (Ramaswamy \& Jayasri 2015) and the Generalized Rayleigh distribution (Ramaswamy \& Jayasri 2014). In comparison to the SSP and DSP, the ChSP-1 is proven to give higher probability of lot acceptance in instances where the acceptance number is set to be zero. An extended version of the ChSP-1 was proposed by Deva Arul and Rebecca (2012), named the two-sided complete chain sampling plan. It is essentially the same as the ChSP-1, where the main difference is that the two-sided complete chain sampling plan also considers the results of the succeeding production lot.

Aslam and Jun (2009) introduced a new approach in acceptance sampling, called the group sampling plan (GSP). The GSP includes a new grouping mechanism where the sampled products are divided into groups consisting of a number of inspectors. By doing so, it enables multiple inspection to take place. Ideally, the GSP is able to further reduce the time taken for inspection. The GSP is also redesigned by Mughal et al. (2016) with the Pareti distribution of the 2nd Kind. In another work, Mughal et al. (2015) proposed a new sampling plan by combining the GSP and the two-sided complete chain sampling plan. The plan is named the new two-sided complete group chain sampling plan (NTSCoGCh). Mughal et al. (2015) tested the plan using the Pareto distribution of the 2 nd Kind and proved that the NTSCoGCh is able to reduce the sample size to be drawn from the production lot while retaining a high probability of acceptance.

Deva Arul and Rebecca (2012) highlighted the word 'complete' in the name of their sampling plan which referred to the five criteria of acceptance of the sampling plan. These five criteria are then adapted by Mughal et al. (2015) for the NTSCoGCh, hence the word 'complete' is retained in the name. However, Mughal (2018) later developed the two-sided group chain sampling plan (TS-GCh) which only considers 3 acceptance criteria. This ultimately means that the TS-GCh is stricter in accepting production lots, thus reducing the possibility of a type-II error occurring. However, it can be said that a stricter sampling plan may also increase the risk of a type-I error. This was not addressed by Mughal (2018) since his study of sampling plans is focused solely on consumer's risk. 
In this study, a new sampling plan is proposed. This plan, which considers 4 acceptance criteria, is named as the new two-sided group chain sampling plan (NTSGCh). It is a more balanced approach with equal focus given on both the producer and consumer, since it is the midground between its predecessors; the producerfocused NTSCoGCh and the consumer-focused TSGCh.

\section{MATERIALS AND METHODS}

\section{TIME TRUNCATED LIFE TEST}

A popular method for inspection of products with long life duration is the truncated life test. In contrast to inspecting the time taken for each product to stop functioning, a truncated life test is stopped at a prespecified termination time, $t_{0}$. Then, the number of defectives, $d$, in between the inspection start time and the termination time is observed. It is the compared against the pre-specified acceptance number, $c$. Generally, the production lot is only accepted if $d$ is less than or equal to $c$. For the purpose of this study, the termination time is denoted as the function $t_{0=} b \mu_{0}$.

\section{OPERATIONAL PROCEDURE OF THE NTSGCh}

Listed herewith is the step-by-step procedure of the NTSGCh with acceptance number $c=1$ : First, draw a sample of size $\eta$ and divide it into $g$ groups of $r$ testers. Then, start the life test. Second, stop the test at $t=t_{0}$. Inspect all units simultaneously and count the number of defectives, $d$. Third, If $d>1$, reject the production lot. Fourth, If $d=0$, accept the production lot given that the preceding and succeeding lots have at most 1 defective unit, $d_{i}+d_{j} \leq 1$, and Fifth, If $d=1$, accept the lot if and only if the cumulative number of defectives in the preceding and succeeding lots is zero, $d_{i}+d_{j}=0$.

\section{THE PROPORTION DEFECTIVE}

The proportion defective, otherwise known as the probability of failure and denoted by $p$, is derived from cumulative distribution function (CDF) of the lifetime distribution being used. The formula of proportion defective is unique to each distribution. In this study, the proportion defective is derived from the Lognormal distribution. Since the NTSCoGCh is conducted using Pareto distribution of the 2nd Kind, the algorithm of the NTSCoGCh will be adapted with the Logrnormal distribution in this study, so that the performance comparison between the two plans can be done using the same distribution. The Lognormal distribution is chosen for the study due to its importance and relevance in the field of reliability engineering (Montgomery \& Runger 2003; O'Connor et al. 2016). The CDF of the Lognormal distribution is as follows:

$$
F(t ; \delta, \gamma)=\Phi\left[\frac{\ln (t)-\gamma}{\delta}\right], t>0, \delta>0, \gamma>0
$$

The scale and shape parameter of the distribution are denoted by $\delta$ and $\gamma$, respectively. Meanwhile, the true mean lifetime of the product is calculated by:

$$
\mu=\exp \left[\gamma+\frac{\delta^{2}}{2}\right]
$$

Then, by substituting (2) and $t_{0}=b \mu_{0}$ into (1), the formula for proportion defective can be further simplified into:

$$
p=\Phi\left[\frac{1}{\delta} \ln \left(\frac{b \mu_{0}}{\mu}\right)+\frac{\delta}{2}\right], \text { where } \delta>0 .
$$

The symbol $\Phi$ refers to the CDF of the Standard Normal distribution. Equation (3) is then calculated using a computer-based simulation program for various values of design parameters which will be discussed in the next section of the paper.

PROBABILITY OF LOT ACCEPTANCE

In this paper, the acceptance number, $c$, is 1 . Therefore, in lot sentencing, it is important in finding 0 or 1 defectives in the sample, since any more defectives than 1 will surely result in the lot being rejected. The probabilities of finding 0 and 1 defective are denoted by $P_{0}$ and $P_{1}$ respectively. NTSGCh considers the same number of preceding and succeeding lots, where $i=j$. Hence, the probabilities of finding 0 and 1 defective in the preceding and succeeding samples are denoted by $P_{0}^{i}$ and $P_{1}^{i}$, respectively. Then, the 4 acceptance criteria can be derived and simplified into the following equation:

$$
P(a)=P_{0}^{i}\left[P_{0}^{i+1}+2 P_{0} P_{1}^{i}+P_{0}^{i} P_{1}\right]
$$

Next, since lot sentencing is Binomial in nature; that is the tested lot can only be accepted or rejected, (4) can be further derived into:

$P(a)=\left[(1-p)^{(g r)}\right]^{i} \times\left[\begin{array}{c}{\left[(1-p)^{(g r)}\right]^{(i+1)}+2(1-p)^{g r} \times} \\ {\left[g r p(1-p)^{g r-1}\right]^{i}+\left[(1-p)^{g r}\right]^{i} \times\left[g r p(1-p)^{g r-1}\right]}\end{array}\right](5)$

In order to fully observe the behavior of the NTSGCh, the design parameters are specified with various values. The values are $r=\{2,3,4,5\}, i=j=\{1,2,3,4\}, b=\{0.25$, $0.5,0.75,1.0,1.25,1.5,1.75,2.0\}, \beta=\{0.25,0.1,0.05$, $0.01\}$, and $\mu / \mu_{0}=\{1,2,4,6,8,10,12\}$.

\section{RESULTS AND DISCUSSION}

There are two observations to be discussed in regard to the performance of the NTSGCh. Firstly, the observation of the minimum number of groups. In this study, the sample size is broken down into $g$ groups of $r$ testers, 
hence $n=g \times r$. Thus, when comparing two or more sampling plans, a lower value of $g$ means a smaller sample size given that the number of testers is the same. Alternatively, $g$ is also defined as the minimum number of groups required when adhering to the pre-specified consumer's risk value. Table 1 lists the values of $g$ under various design parameters.

TABLE 1. The minimum number of groups for the Lognormal distribution

\begin{tabular}{|c|c|c|c|c|c|c|c|c|c|c|}
\hline & & & & & & & & & & \\
\hline$\beta$ & $r$ & $i$ & 0.25 & 0.5 & 0.75 & 1 & 1.25 & 1.5 & 1.75 & 2 \\
\hline \multirow{5}{*}{0.1} & 2 & 1 & 4 & 1 & 1 & 1 & 1 & 1 & 1 & 1 \\
\hline & 3 & 2 & 2 & 1 & 1 & 1 & 1 & 1 & 1 & 1 \\
\hline & & & & & & & & & & \\
\hline & 4 & 3 & 1 & 1 & 1 & 1 & 1 & 1 & 1 & 1 \\
\hline & 5 & 4 & 1 & 1 & 1 & 1 & 1 & 1 & 1 & 1 \\
\hline \multirow{5}{*}{0.05} & 2 & 1 & 4 & 1 & 1 & 1 & 1 & 1 & 1 & 1 \\
\hline & 3 & 2 & 2 & 1 & 1 & 1 & 1 & 1 & 1 & 1 \\
\hline & & & & & & & & & & \\
\hline & 4 & 3 & 1 & 1 & 1 & 1 & 1 & 1 & 1 & 1 \\
\hline & 5 & 4 & 1 & 1 & 1 & 1 & 1 & 1 & 1 & 1 \\
\hline \multirow{5}{*}{0.01} & 2 & 1 & 6 & 1 & 1 & 1 & 1 & 1 & 1 & 1 \\
\hline & 3 & 2 & 3 & 1 & 1 & 1 & 1 & 1 & 1 & 1 \\
\hline & & & & & & & & & & \\
\hline & 4 & 3 & 2 & 1 & 1 & 1 & 1 & 1 & 1 & 1 \\
\hline & 5 & 4 & 1 & 1 & 1 & 1 & 1 & 1 & 1 & 1 \\
\hline
\end{tabular}

The information in Table 1 can be interpreted through the formula of $n=g \times r$. For instance, consider a company implementing the NTSGCh in their inspection. The company is willing to adhere to $5 \%$ consumer's risk $(\beta=0.05)$ and are appointing four employees for the inspection process $(r=4)$. From Table 1 , the minimum number of groups yielded for the company's situation is $g=1$ for all duration of life tests $(b)$. Hence, the sample size to be drawn from the production lot is 6 units. Also, the responding number of preceding and succeeding lots to be considered for the NTSGCh is 3 .

Secondly, the truncated life test simulation also produces the probability of lot acceptance for the NTSGCh. The probability of lot acceptance indicates the probability that the lot being tested will comply to any one of the four acceptance criteria and not being rejected. Table 2 lists the probability of lot acceptance for the NTSGCh. 
TABLE 2. The probability of lot acceptance for the Lognormal distribution

\begin{tabular}{|c|c|c|c|c|c|c|c|c|c|}
\hline \multicolumn{10}{|c|}{$\mu / \mu_{0}$} \\
\hline$\beta$ & $g$ & $b$ & 1 & 2 & 4 & 6 & 8 & 10 & 12 \\
\hline \multirow{8}{*}{0.1} & 1 & 0.25 & 0.0104 & 0.2448 & 0.7567 & 0.9148 & 0.9644 & 0.9830 & 0.9911 \\
\hline & 1 & 0.50 & 0.0000 & 0.0019 & 0.1504 & 0.4646 & 0.6895 & 0.8171 & 0.8880 \\
\hline & 1 & 0.75 & 0.0000 & 0.0000 & 0.0172 & 0.1504 & 0.3639 & 0.5528 & 0.6895 \\
\hline & 1 & 1.00 & 0.0000 & 0.0000 & 0.0019 & 0.0365 & 0.1504 & 0.3102 & 0.4646 \\
\hline & 1 & 1.25 & 0.0000 & 0.0000 & 0.0002 & 0.0081 & 0.0528 & 0.1504 & 0.2774 \\
\hline & 1 & 1.50 & 0.0000 & 0.0000 & 0.0000 & 0.0019 & 0.0172 & 0.0657 & 0.1504 \\
\hline & 1 & 1.75 & 0.0000 & 0.0000 & 0.0000 & 0.0005 & 0.0056 & 0.0270 & 0.0758 \\
\hline & 1 & 2.00 & 0.0000 & 0.0000 & 0.0000 & 0.0001 & 0.0019 & 0.0109 & 0.0365 \\
\hline \multirow{8}{*}{0.05} & 1 & 0.25 & 0.0104 & 0.2448 & 0.7567 & 0.9148 & 0.9644 & 0.9830 & 0.9911 \\
\hline & 1 & 0.50 & 0.0000 & 0.0019 & 0.1504 & 0.4646 & 0.6895 & 0.8171 & 0.8880 \\
\hline & 1 & 0.75 & 0.0000 & 0.0000 & 0.0172 & 0.1504 & 0.3639 & 0.5528 & 0.6895 \\
\hline & 1 & 1.00 & 0.0000 & 0.0000 & 0.0019 & 0.0365 & 0.1504 & 0.3102 & 0.4646 \\
\hline & 1 & 1.25 & 0.0000 & 0.0000 & 0.0002 & 0.0081 & 0.0528 & 0.1504 & 0.2774 \\
\hline & 1 & 1.50 & 0.0000 & 0.0000 & 0.0000 & 0.0019 & 0.0172 & 0.0657 & 0.1504 \\
\hline & 1 & 1.75 & 0.0000 & 0.0000 & 0.0000 & 0.0005 & 0.0056 & 0.0270 & 0.0758 \\
\hline & 1 & 2.00 & 0.0000 & 0.0000 & 0.0000 & 0.0001 & 0.0019 & 0.0109 & 0.0365 \\
\hline \multirow{8}{*}{0.01} & 2 & 0.25 & 0.0001 & 0.0636 & 0.5721 & 0.8366 & 0.9300 & 0.9663 & 0.9822 \\
\hline & 1 & 0.50 & 0.0000 & 0.0019 & 0.1504 & 0.4646 & 0.6895 & 0.8171 & 0.8880 \\
\hline & 1 & 0.75 & 0.0000 & 0.0000 & 0.0172 & 0.1504 & 0.3639 & 0.5528 & 0.6895 \\
\hline & 1 & 1.00 & 0.0000 & 0.0000 & 0.0019 & 0.0365 & 0.1504 & 0.3102 & 0.4646 \\
\hline & 1 & 1.25 & 0.0000 & 0.0000 & 0.0002 & 0.0081 & 0.0528 & 0.1504 & 0.2774 \\
\hline & 1 & 1.50 & 0.0000 & 0.0000 & 0.0000 & 0.0019 & 0.0172 & 0.0657 & 0.1504 \\
\hline & 1 & 1.75 & 0.0000 & 0.0000 & 0.0000 & 0.0005 & 0.0056 & 0.0270 & 0.0758 \\
\hline & 1 & 2.00 & 0.0000 & 0.0000 & 0.0000 & 0.0001 & 0.0019 & 0.0109 & 0.0365 \\
\hline
\end{tabular}

The mean ratio, $\mu / \mu_{0}$, refers to the ratio of the true mean lifetime of the product to its specified mean lifetime. Therefore, if the mean ratio is a positive integer, this means that the production process generally produces products that lasts longer than its mean lifetime. The information in Table 2 lists down the probability of lot 
acceptance with mean ratio $\mu / \mu_{0}=\{1,2,4,6,8,10,12\}$. It can be observed that the higher the mean ratio, the higher the responding probability of lot acceptance. This means that it is less likely to find defective products in a sample from a production lot with higher mean ratio. The probability of lot acceptance also increases when the specified time constant, $b$, is low. Since $t_{0}=b \mu_{0}$, a low value of $b$ means that the life test is conducted for a shorter time. Given that all other parameters are the same, it is less likely to find defective products in a shorter life test. Hence, the yielded probability of lot acceptance is higher when the specified time constant is lower.

For a clearer illustration, consider the same company in the previous example. The company produces an electrical component in production lots of 100 units with known specified mean lifetime of $1000 \mathrm{~h}$. To reduce the time taken during inspection, the company wants to truncate the life test at $500 \mathrm{~h}(b=0.50)$. It is now known that the design parameters for the inspection are $(\beta, r, i, g, b)=(0.05,4,3,1,0.50)$. Thus, 4 units of the electrical component will be inspected simultaneously by 4 testers in a group. The whole production lot will be accepted if: there are no defectives found among the 4 units given that the three preceding and succeeding lots have at most 1 defective cumulatively; or if there are at most 1 defective among the 4 units given that the three preceding and succeeding lots observed no defectives during their inspection. The inspection may produce a probability of lot acceptance in the range of 0.0000 to 0.8880 , depending on the mean ratio of the products between 1 to 12 .

\section{COMPARISON TO ESTABLISHED SAMPLING PLANS}

This section of the paper will compare the performance of the NTSGCh to its predecessors; the NTSCoGCh by Mughal et al. (2015) and the TS-GCh by Mughal (2018). The truncated life test simulation is conducted again using the algorithms of the NTSCoGCh and the TS-GCh. The findings of all three sampling plans are then compared based on two parameters, which are the minimum number of groups and also the probability of lot acceptance.

The difference between the three sampling plans can be seen across all permutations of the parameters, albeit it is most distinctive when the parameters are set as $\{\beta, r, i\}=\{0.05,2,1\}$. The minimum number of groups required for sampling for each plan can be seen in Table 3.

TABLE 3. The minimum number of groups required for each sampling plan when $\beta=0.05, r=2$, and $i=1$

\begin{tabular}{cccc}
\hline$a$ & TS-GCh & NTSGCh & NTSCoGCh \\
\hline 0.25 & 4 & 4 & 5 \\
0.50 & 1 & 1 & 1 \\
0.75 & 1 & 1 & 1 \\
1.00 & 1 & 1 & 1 \\
1.25 & 1 & 1 & 1 \\
1.50 & 1 & 1 & 1 \\
1.75 & 1 & 1 & 1 \\
2.00 & 1 & 1 & \\
\hline
\end{tabular}

As it can be observed in Table 3, the proposed NTSGCh managed to yield the same minimum number of groups as the TS-GCh, one less than the NTSCoGCh. This means that it is as cost effective as the TS-GCh in terms of implementation, due to the fact that it requires less inspection of product. In order to compare the performance of the sampling plans, Table 4 lists the yielded probability of lot acceptance for the three sampling plans at $a=0.25$, which is the shortest duration of the truncated life test. 
TABLE 4 . The probability of lot acceptance when $\beta=0.05, r=2, i=1$ and $a=0.25$

\begin{tabular}{cccc}
\hline & TS-GCh & NTSGCh & NTSCoGCh \\
\cline { 2 - 4 } & \multicolumn{1}{c}{$g$} & \\
\cline { 2 - 4 } 1 & 0.0320 & 0.0445 & 0.0359 \\
2 & 0.4800 & 0.5982 & 0.5454 \\
4 & 0.8984 & 0.9690 & 0.9629 \\
6 & 0.9692 & 0.9964 & 0.9957 \\
8 & 0.9877 & 0.9994 & 0.9993 \\
10 & 0.9942 & 0.9999 & 0.9998 \\
12 & 0.9970 & 1.0000 & 1.0000 \\
\hline
\end{tabular}

As depicted in Table 4, the NTSGCh produces the best probability of lot acceptance in comparison to the other two sampling plans. In contrast to the TS-GCh, the NTSGCh produces higher probability of lot acceptance due to its leniency in having one more acceptance criterion. On the other hand, the higher minimum number of groups for the NTSCoGCh compromised its probability of lot acceptance. Although it is more lenient in comparison to the NTSGCh, having two additional products $(r=2)$ for inspection opens up the possibility of finding more defective products, hence lowering its probability of lot acceptance.

\section{CONCLUSION}

This paper proposes the NTSGCh as a new approach in acceptance sampling. Since it gives a neutral focus on both the producer and consumer, the NTSGCh can be seen as a more balanced approach in lot sentencing as compared to its two immediate predecessors, the twosided complete chain sampling plan and the NTSCoGCh. The findings proved that the NTSGCh yields a high probability of lot acceptance drawn from a minimum number of groups for the sample. The experiment conducted using the Lognormal distribution proved that the NTSGCh outperformed its predecessors. Hence, it can be said that the NTSGCh is a good alternative for producers in the manufacturing industry.

\section{REFERENCES}

Aslam, M. 2007. Double acceptance sampling based on truncated life tests in Rayleigh Distribution. European Journal of Scientific Research 17: 605-611.
Aslam, M. \& Jun, C.H. 2010. A double acceptance sampling plan for Generalized Log-Logistic Distribution with known shape parameters. Journal of Applied Statistics 37(3): 405414.

Aslam, M. \& Jun, C.H. 2009. A group acceptance sampling plan for truncated life test having Weibull Distribution. Journal of Applied Statistics 36(9): 1021-1027.

Aslam, M., Jun, C.H. \& Ahmad, M. 2009. A double acceptance sampling plan based on truncated life test in the Weibull distribution. Journal of Statistics Theory and Applications 8(2): 191-206.

Deva Arul, S. \& Rebecca, I.E.K. 2012. Two-sided complete chain sampling plans for attribute quality characteristics (CChSP-0,1). Karunya Journal of Research 3(1): 8-16.

Dodge, H.F. 1955. Chain sampling inspection plan. Industry Quality Control 11(4): 10-13.

Goode, H.P. \& Kao, J.H.K. 1961. Sampling plans based on the Weibull Distribution. Proceedings of the Seventh National Symposium on Reliability and Quality Control. pp. 24-40.

Kantam, R., Rosaiah, K. \& Rao, G.S. 2001. Acceptance sampling based on life tests: Log- logistic model. Journal of Applied Statistics 28(1): 121-128.

Montgomery, D.C. 2009. Introduction to Statistical Quality Control. 6th ed. New Jersey: John Wiley \& Sons.

Montgomery, D.C. \& Runger, G.C. 2003. Applied Statistics and Probability for Engineers. 3rd ed. New Jersey: John Wiley \& Sons.

Mughal, A.R. 2018. A family of group chain acceptance sampling plans based on truncated life test. Doctoral Thesis. Ph.D. Universiti Utara Malaysia, Sintok (Unpublished).

Mughal, A.R., Zain, Z. \& Aziz, N. 2016. Time truncated efficient testing strategy for Pareto distribution of the 2 nd kind using Weighted Poisson and Poisson Distribution. Sains Malaysiana 45(11): 1763-1772. 
Mughal, A.R., Zain, Z. \& Aziz, N. 2015. New two-sided complete group chain sampling plan for Pareto distribution of the 2nd kind. Research India Publication 10(12): 31855-31860.

O'Connor, A.N., Modarres, M. \& Mosleh, A. 2016. Probability Distributions Used in Reliability Engineering. Maryland: University of Maryland.

Ramaswamy, A.R.S. \& Jayasri, S. 2014. Time truncated chain sampling for Generalized Rayleigh distribution. International Refereed Journal of Engineering and Sciences 3(2): 49-53.

Ramaswamy, A.R.S. \& Jayasri, S. 2015. Time truncated chain sampling for Weibull Distribution. International Journal of Engineering Research and General Science 3(2): 59-67.

Rosaiah, K. \& Kantam, R. 2005. Acceptance sampling based on the Inverse Rayleigh Distribution. Economic Quality Control 20(2): 277-286.

School of Quantitative Sciences

College of Arts and Science

Universiti Utara Malaysia

06010 Sintok, Kedah Darul Aman

Malaysia

*Corresponding author; email: faroukzainolkamal@gmail.com

Received: 18 April 2019

Accepted: 24 January 2020 